\section{Pengembangan Media Pembelajaran E-Magazine sebagai Sumber Belajar Biologi Siswa Kelas XII}

\author{
Ainul Fuad \\ Hilda Karim \\ Muhiddin Palennari
}

\begin{abstract}
Abstrak. Penelitian ini bertujuan untuk mengembangkan media pembelajaran berupa majalah elektronik (e-magazine) pada pokok bahasan perrtumnbuhan dan perkembangan pada tumbuhan, penelitian ini merupakan penelitian pengembangan research and development (R\&D) menggunakan model ADDIE, untuk uji kevalidan media dan materi berdasarkan hasil penilaian dari 2 validator ahli, sedangkan uji kepraktisan dilakukan guru dan siswa terhadap penggunaan media. Tahap pengembangan dilakukan dengan cara validasi e-magazine, kemudian di

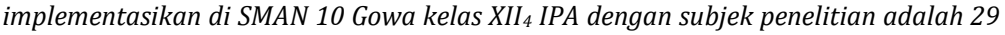
siswa. Teknik pengumpulan data yang digunakan adalah observasi, wawancara, dan angket. Hasil penelitian menunjukkan hasil uji validitas dengan rata-rata persentase kelayakan media sebesar $82 \%$. Sedangkan kelayakan materi dengan persentase keseluruhan yaitu 81\%, keduanya berada pada kategori sangat layak. Adapun hasil uji coba lapangan pada respon guru dan siswa diperoleh nilai keseluruhan $83 \%$ dari respon guru dan uji coba siswa diperoleh nilai 81\%, keduanya berada pada kategori respon positif. Dari penilaian kelayakan yang ditinjau berdasarkan validitas dan kepraktisan dapat disimpulkan bahwa e-magazine sebagai sumber belajar bersifat valid dan praktis.

Kata Kunci: e-magazine, kevalidan, kepraktisan, Pertumbuhan dan Perkembangan pada Tumbuhan.
\end{abstract}

\section{Pendahuluan}

Memasuki era dalam pengembangan IPTEK yang berkembang pesat saat ini, telah memberikan banyak manfaat, salah satunya dalam bidang pendidikan. Dalam meningkatkan mutu pendidikan generasi muda wajib dan harus mampu untuk memanfaatkan serta mengaplikasikan diberbagai bidang khususnya bidang pendidikan, kemajuan dan perkembangan pendidikan menjadi faktor keberhasilan suatu bangsa. Pembelajaran dapat dikatakan berhasil ketika siswa aktif dalam proses belajar mengajar, menurut Falahudin (2014). Penggunaan media pembelajaran dalam proses belajar mengajar dapat meningkatkan minat dan keinginan baru, membangkitkan motivasi dan rangsangan belajar, serta membawa pengaruh-pengaruh psikologis terhadap siswa. Oleh karena itu guru diarahkan agar memanfaatkan teknologi dalam merancang media pembelajaran, sehingga dapat meningkatkan minat baca siswa. Media merupakan alat saluran komunikasi. Media berasal dari bahasa Latin dan merupakan bentuk jamak dari kata "medium" yang secara harfiah berarti "perantara" yaitu perantara sumber pesan (a source) dengan penerima pesan (a receiver). Media pembelajaran selalu terdiri atas dua unsur penting, yaitu unsur peralatan atau perangkat keras (hardware) dan unsur pesan yang dibawanya (message/software). Dengan demikian, media pembelajaran memerlukan peralatan untuk menyajikan pesan, namun yang terpenting bukanlah peralatan itu, tetapi pesan atau
Biology Teaching and Learning

p-ISSN $2621-5527$

e-ISSN 2621 - 5535

Abstract. This Research and Development $(R$ and $D)$ concerns on learning media development regarding electronic magazine (e-magazine) for Plant Growth and Development subject. The $R$ and $D^{\prime}$ s model used Analyze, Design, Develop, Implement, Evaluate (ADDIE). Validity test obtained from two expert validators and Practicality test obtained from the using of media by teacher and students.

The Develop stage of this study conducted by validating e-magazine for further be implemented on SMAN 10 Gowa, Class of $\mathrm{XII}_{4}$ Natural Science. The number of subjects comprised of 29 students. Data collected from interview, observation and questionnaire. The result of validity test showed the average of media feasibility percentage is $82 \%$. While the subject matter feasibility gained $81 \%$. Both of these result showed very decent category which was meant that the media is feasible to be used. The average of teacher and students respond gained $83 \%$ and 81 $\%$ respectively toward positive respond. From the point of feasibility which had been evaluated by validity and practical test, this study can be conclude that e magazine is valid and practice learning media to be implemented in learning process.

Keywords: e-magazine, validity, practicality, plant growth and development.

Ainul Fuad

Universitas Negeri Makassar Indonesia

Hilda Karim

Universitas Negeri Makassar Indonesia

Muhiddin Palennari Universitas Negeri Makassar Indonesia 
informasi belajar yang dibawakan oleh media tersebut (Rudi, 2007). Media sumber belajar adalah alat bantu yang berguna dalam kegiatan belajar mengajar. Alat bantu dapat mewakili sesuatu yang tidak dapat disampaikan guru melalui kata-kata atau kalimat. Kesulitan siswa memahami konsep dan prinsip tertentu dapat diatasi dengan bantuan alat bantu. Bahkan alat bantu diakui dapat melahirkan umpan balik yang baik dari anak didik. Dengan memanfaatkan taktik alat bantu yang mudah diterima (acceptable), guru dapat menggairahkan minat belajar siswa. (Nugrahani,2007).

Berdasarkan hasil observasi dan wawancara di SMAN 10 Gowa yang dilakukan oleh peneliti terdapat beberapa permasalahan dalam proses pembelajaran yakni penggunaan media pembelajaran disekolah ini masih sangat kurang diberikan, guru cenderung menggunakan metode pembelajaran langsung tanpa ada hubungan interaktif terhadap guru dan siswa proses pembelajaran komunikasi hanya terjadi pada satu arah yaitu guru tanpa ada umpan balik dari pelajar, hal ini menyebabkan siswa tidak aktif dalam proses pembelajaran hanya menunggu guru menjelaskan selanjutnya mengerjakan tugas yang diberikan. Untuk materi pelajaran khususnya materi biologi siswa dituntut memiliki daya nalar yang kuat karena pada materi biologi terdapat beberapa proses atau mekanisme bahkan sampai nama latin yang tersedia, sehingga dalam pembelajarannya siswa memerlukan alat bantu atau peraga dalam proses pembelajaran agar pesan dapat tersampaikan jelas dan tepat. Dari hasil wawancara guru biologi kelas XII semester ganjil mengatakan bahwa setiap siswa dalam satu kelas memiliki daya serap yang berbeda-beda ada yang lambat dan ada yang cepat dalam menerima materi sehingga memerlukan media pembelajaran untuk mempermudah guru dalam menyelaraskan pemahaman siswa. hal senada dikemukakan Falahudin (2014), setiap pembelajar mempunyai penafsiran yang berbeda-beda terhadap suatu konsep materi pelajaran tertentu, dengan bantuan media penafsiran yang beragam dapat dihindari sehingga dapat menyampaikan informasi secara seragam ke pembelajar.

E-magazine atau majalah elektronik merupakan sumber belajar yang berisi materi pembelajaran yang ditampilkan secara menarik dengan berbagai fitur pendukung seperti gambar, video, dan audio (Falahudin,2014). Peserta didik dapat melihat langsung video sesuai dengan materi yang disajikan dengan menggunakan sumber belajar elektronik. Salah satu keunggulan e-magazine menggunakan flipcreator yaitu dapat dioperasikan menggunakan laptop atau komputer tanpa harus menginstall software aplikasi flipcreator kecuali membuat produk baru yang diinginkan, selain itu sumber belajar ini dapat dibuka tanpa harus terkoneksi dengan jaringan internet atau wireless serta pengurangan penggunaan kertas secara berkala.Berdasarkan hasil penelitian Yulianto (2013), pengembangan majalah biologi dapat meningkatkan motivasi belajar dan kreatifitas peserta didik. Hal ini membuktikan adanya potensi pengembangan majalah elektronik sebagai sumber belajar biologi dalam memahami materi pelajaran.

Berdasarkan latar belakang tersebut, maka peneliti tertarik untuk melakukan penelitian pengembangan mengenai "Pengembangan Media Pembelajaran E-Magazine Sebagai Sumber Belajar Biologi Siswa” Sekolah Menengah Atas.

\section{Metode Penelitian}

\section{Jenis Penelitian}

Jenis penelitian yang digunakan dalam penelitian ini adalah pengembangan (Research and Development) yakni pengembangan e-magazine menggunakan flipcreator pada materi pertumbuhan dan perkembangan pada tumbuhan sebagai sumber belajar kelas XII SMA/MA, dalam penelitian ini digunakan model ADDIE. Model ADDIE terdiri dari 5 (lima) langkah yaitu: (1) analisis (analyze), (2) perancangan (design), (3) pengembangan (development), (4) implementasi (implementation), dan (5) evaluasi (evaluation) 


\section{Hasil dan Pembahasan}

\section{Hasil Penelitian}

Tahap analisis, berdasarkan hasil observasi di lapangan bahwa pemberian sumber belajar yang inovatif sangat jarang dan bahkan tidak pernah diberikan pada saat proses pembelajaran. Tahap desain, perancangan sumber belajar e-magazine menggunakan beberapa aplikasi seperti photoshop, Corel Draw X8, Adobe Primer CC , dan flipcreator. Tahap pengembangan, validasi sumber belajar e-magazine dilakukan sebanyak 4 kali, dan 2 kali revisi total layout yang dinilai oleh 2 validator. Tahap implementasi, dengan pemberian sumber belajar yang dikemas dalam bentuk flashdisk, selanjutnya peneliti memberikan instrumen respon guru 3 orang dan respon peserta didik 29 orang. Tahap evaluasi, yaitu mengevaluasi hasil dari implementasi sumber belajar terhadap respon guru dan peserta didik. Adapun hasil data kevalidan dan data kepraktisan sumber belajar e-magazine dapat dilihat pada Tabel 1, 2, 3, dan 4 .

Tabel 1. Analisis Data Uji kevalidan Sumber Belajar oleh Validator

\begin{tabular}{|c|c|c|c|}
\hline No. & $\begin{array}{c}\text { Aspek } \\
\text { Penilaian }\end{array}$ & $\begin{array}{c}\text { Skor } \\
\text { Kevalidan }\end{array}$ & Keterangan \\
\hline 1 & Komposisi Penulisan & 3.9 & Valid \\
\hline 2 & Tampilan & 3.8 & Valid \\
\hline 3 & Kelayakan Fitur & 4.3 & Valid \\
\hline \multicolumn{2}{|c|}{ Total Skor } & $\mathbf{3 . 4}$ & Valid \\
\hline
\end{tabular}

Hasil penilaian validator terhadap kevalidan sumber belajar untuk masing-masing aspek berada pada kategori valid. Sementara untuk rata-rata penilaian secara keseluruhan yakni skor 3.4 dengan kategori "valid.

Tabel 2. Analisis Data Kevalidan Materi oleh Validator

\begin{tabular}{|c|c|c|c|}
\hline No. & $\begin{array}{c}\text { Aspek } \\
\text { Penilaian }\end{array}$ & $\begin{array}{c}\text { Skor Rata- } \\
\text { rata }\end{array}$ & Keterangan \\
\hline 1 & Penyajian Materi & 3.9 & Valid \\
\hline 2 & Bahasa & 3.8 & Valid \\
\hline 3 & $\begin{array}{c}\text { Kesesuaian tingkat berpikir peserta } \\
\text { didik }\end{array}$ & 4.1 & Valid \\
\hline & Total Skor & $\mathbf{3 . 9}$ & Valid \\
\hline
\end{tabular}

Hasil penilaian validator terhadap penilaian materi untuk masing-masing aspek berada pada kategori valid. Sementara untuk rata-rata penilaian secara keseluruhan yakni skor 4.6 dengan kategori "valid".

Tabel 3. Hasil Analisis Data Respon Guru

\begin{tabular}{|c|c|c|c|}
\hline No. & $\begin{array}{c}\text { Aspek } \\
\text { Penilaian }\end{array}$ & $\begin{array}{c}\text { Skor Rata- } \\
\text { rata }\end{array}$ & Keterangan \\
\hline 1 & Kemanfaatan & 93 & Valid \\
\hline 2 & Tampilan & 80 & Valid \\
\hline 3 & Interaksi & 88 & Valid \\
4 & Kepuasan & 86 & Valid \\
\hline
\end{tabular}

Hasil respon guru terhadap sumber belajar termasuk dalam kategori positif dengan ratarata keseluruhan respon guru yaitu $81 \%$, melihat kategori kepraktisan $70 \% \leq \mathrm{RS}<85 \%$, dapat dinyatakan bahwa sumber belajar e-magazine bersifat praktis jika ditinjau dari respon guru. 
Tabel 4. Hasil Analisis Data Respon Siswa

\begin{tabular}{|c|c|c|c|}
\hline No. & $\begin{array}{c}\text { Aspek } \\
\text { Penilaian }\end{array}$ & Skor Rata-rata & Keterangan \\
\hline 1 & Kemanfaatan & 86 & Valid \\
\hline 2 & Tampilan & 78 & Valid \\
\hline 3 & Interaksi & 85 & Valid \\
4 & BelajarMandri & 94 & Valid \\
\hline
\end{tabular}

Hasil respon peserta didik terhadap sumber belajar termasuk dalam kategori positif dengan rata-rata keseluruhan respon peserta didik yaitu $84.18 \%$, melihat kategori kepraktisan $70 \% \leq$ RS $<85 \%$, sehingga dapat dinyatakan bahwa sumber belajar e-magazine bersifat praktis jika ditinjau dari respon peserta didik.

\section{Pembahasan}

Sumber belajar e-magazine merupakan salah satu terobosan dalam pemanfaatan teknologi untuk memperbaiki kualitas pembelajaran didalam kelas. Sumber belajar sangat besar peranannya dalam proses pembelajaran sehingga perlu dikembangkan dan dikelola secara sistematik, bermutu dan fungsional. (Wiratmojo, 2002) menjelaskan bahwa penggunaan sumber belajar yang inovatif dapat membangkitkan minat, motivasi dan rangsangan dalam proses pembelajaran, sehingga sangat membantu dalam penyampaian pesan kepada peserta didik pada saat proses pembelajaran. Oleh karena itu, penelitian ini bertujuan mengembangkan sumber belajar e-magazine menggunakan flipcreator pada materi pertumbuhan dan perkembangan pada tumbuhan kelas XII yang bersifat valid dan praktis.

Tahap analisis, sumber belajar yang dikembangkan adalah sumber belajar e-magazine menggunakan flipcreator pada materi pertumbuhan dan perkembangan pada tumbuhan kelas XII SMA/MA. Analisis kebutuhan peserta didik terhadap sumber belajar, berdasarkan hasil observasi di lapangan bahwa pemberian sumber belajar yang inovatif sangat jarang dan bahkan tidak pernah diberikan pada saat proses pembelajaran, sedangkan kebutuhan peserta didik akan metode pembelajaran yang bervariasi sangat diperlukan dalam hal ini pemberian sumber belajar, untuk membangkitkan motivasi belajar dan proses pembelajaran aktif.

Tahap desain, setelah didapatkan data analisis kebutuhan peserta didik dan penyesuaian topik pelajaran yang dibutuhkan dalam pengembangan sumber belajar e-magazine, selanjutnya merancang struktur dari komponen lembar instrumen penelitian dan perancangan sumber belajar e-magazine, yakni dari materi dan layout sumber belajar. Perancangan sumber belajar dengan menggunakan beberapa aplikasi seperti photoshop, adobe primer CC, corel draw X8, dan aplikasi untuk menampilkan sumber belajar yakni dalam bentuk majalah digital yaitu flipcreator.

Tahap implementasi, produk yang telah divalidasi dan dinyatakan valid oleh validator ahli maka proses selanjutnya yakni diimplementasikan ke guru dan peserta didik, dengan pemberian sumber belajar yang dikemas dalam bentuk $C D$ dan juga flashdisk, setelah pemberian sumber belajar dan melihat produk e-magazine, selanjutnya peneliti memberikan instrumen respon guru dan peserta didik untuk uji kepraktisan sumber belajar.

Tahap evaluasi, tahap ini mengevaluasi hasil dari implementasi sumber belajar terhadap guru dan peserta didik. Berdasarkan analisis data yang diperoleh dapat disimpulkan dengan melihat hasil persentase guru dan peserta didik terhadap sumber belajar e-magazine menggunakan flipcreator yang bersifat praktis".

Sebelum dilakukan validasi sumber belajar terlebih dahulu dilakukan validasi terhadap instrumen penilaian. Penilaian instrumen bertujuan untuk menilai kelayakan instrumen penilaian. 
Pengembangan Media Pembelajaran

E-Magazine sebagai Sumber Belajar Biologi Siswa Kelas XII

(hlm. 38-45)

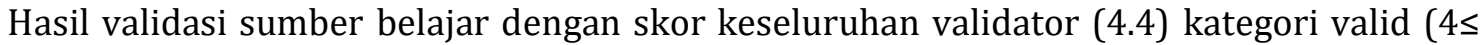
Va $<5)$ sehingga dapat disimpulkan sumber belajar e-magazine ini bersifat valid. Menurut Suherman (2009), pembelajaran menggunakan sumber belajar akan lebih menarik perhatian peserta didik, kejelasan dan daya tarik gambar menimbulkan rasa keingintahuan peserta didik lebih tinggi, hal yang menunjukkan bahwa sumber belajar e-magazine menggunakan flipcreator memiliki aspek meningkatkan motivasi belajar peserta didik.

Hasil penilaian validator sumber belajar dengan skor penilaian yang tidak mencapai angka maksimum 5.0 maka terdapat beberapa kekurangan yang harus ditingkatkan lagi dalam penelitian selanjutnya, yakni penambahan beberapa vitur seperti video pembelajaran praktikum yang dapat membuat peserta didik lebih aktif dan dapat digunakan secara mandiri. Selain itu perlu adanya penambahan fitur evaluasi berupa teka-teki silang untuk membuat sumber belajar e-magazine ini lebih bersifat interaktif. Menurut Ronal (2009), video dapat menjadi alat bantu pembelajaran yang ampuh bila digunakan secara efektif seperti membantu peserta didik melihat hal-hal yang mungkin tak pernah mereka alami dan menjadikan hal-hal yang mereka baca menjadi hidup.

Validasi materi dilakukan untuk melihat kelayakan materi yang disajikan dalam sumber belajar e-magazine menggunakan flipcreator, terdiri dari 3 aspek kriteria penilaian yaitu penyajian materi, kebahasaan, dan kesesuaian tingkat berpikir peserta didik. Merujuk pada hasil validasi materi dengan skor keseluruhan validator yakni kategori valid. Penggunaan sumber belajar e-magazine menggunakan flipcreator di kelas menunjukkan hal positif, seperti pencapaian materi baku, peserta didik melihat dan mendengar penyajian melalui sumber belajar menerima pesan yang sama meskipun guru menafsirkan isi pelajaran dengan cara berbeda-beda, materi lebih terorganisasikan dengan baik, spesifik dan jelas (Suherman, 2009).

Penyajian materi dengan kategori valid namun dalam penilaian tidak mencapai nilai maksimum yakni 5.0 dengan melihat beberapa yang harus ditingkatkan, dalam hal ini aspek materi yang disajikan dalam e-magazine yaitu kurangnya kalimat atau info menarik yang berhubungan dengan materi yang disajikan, sehingga belum menjadi perhatian penuh oleh peserta didik, pada dasarnya suatu majalah merupakan sumber belajar yang menyajikan suatu informasi yang lugas yang disajikan secara jelas dan menarik, dan lebih banyak menggunakan bahasa yang persuasif untuk pembaca. Beberapa cara digunakan untuk menarik perhatian pada media berbasis teks adalah warna, huruf dan kotak, warna digunakan sebagai alat penuntun dan penarik perhatian informasi yang penting, memberikan penekanan-penekanan terhadap setiap kata yang dianggap penting (Suherman, 2009).

Kepraktisan sumber belajar e-magazine menggunakan flipcreator dapat dilihat dari respon guru dan respon peserta didik, berdasarkan hasil analisis data penelitian maka ada beberapa kriteria instrumen yang diberikan pada respon guru dan peserta didik, aspek penilaian terhadap guru yaitu kemanfaatan sumber belajar, tampilan, interaksi, dan kepuasan. Hasil analisis data respon guru bersifat positif sehingga dinyatakan praktis.

Uji kepraktisan guru dalam penggunaan sumber belajar e-magazine menggunakan flipcreator, yaitu guru dapat menyampaikan informasi lebih jelas dan tepat, dapat ditanggapi dan dimengerti oleh peserta didik secara cepat dan jelas, guru dapat menggunakan sumber belajar tanpa perlu menjelaskan mulai dari awal karena sumber belajar e-magazine menggunakan flipcreator telah dilengkapi dengan beberapa fitur tambahan seperti video audio dan gambar yang mempermudah aktivitas pembelajaran di kelas, sehingga guru dapat mengefisien waktu pembelajaran. Menurut Suherman (2009), sumber belajar inovatif mampu menyajikan materi secara baik dan jelas, pembelajaran menjadi lebih interaktif dengan melibatkan partisipasi, umpan balik dan penguatan peserta didik dalam pembelajaran, memerlukan waktu yang singkat dalam mengantarkan pesan-pesan dan isi pembelajaran, sehingga beban guru dalam menjelaskan berulang-berulang mengenai materi hilang dan memusatkan perhatian peserta didik kepada aspek penting lain dalam proses mengajar.

Setelah memperoleh hasil respon guru dengan kategori positif, namun dapat dilihat bahwa hasil penilaian tersebut tidak mencapai hasil maksimal yakni mencapai $100 \%$ dari 
kepraktisan sumber belajar yang diberikan, hal ini dapat dilihat dari beberapa faktor seperti faktor usia dan kondisi guru, yang dimana guru yang berada di sekolah tempat melakukan penelitian, guru sangat jarang menggunakan sumber belajar yang inovatif dalam proses pembelajarannya, sehingga dalam penggunaan sumber belajar yang menggunakan alat bantu elektronik merasa akan lebih rumit untuk dilaksanakan.

Hasil analisis uji respon peserta didik yang telah dilakukan, yaitu terdiri 4 indikator pernyataan yaitu, kemanfaatan sumber belajar, tampilan, interaksi, dan belajar mandiri. Diperoleh rata-rata respon peserta didik yakni berada pada kategori positif atau sumber belajar tergolong praktis. Hal tersebut senada yang dikemukakan Yamasari (2010) bahwa sumber belajar dinyatakan praktis apabila praktis secara praktik yaitu respon peserta didik dan respon guru terhadap sumber belajar menunjukkan kategori positif.

Berdasarkan hasil penilaian respon peserta didik yang dapat di kategorikan praktis namun dalam penilaian ini tidak mencapai hasil maksimal yakni $100 \%$ dapat dilihat dari beberapa faktor yang ada, kurangnya informasi unik dan terbaharui menjadi salah satu penyebab peserta didik tidak memberikan perhatian penuh terhadap sumber belajar yang diberikan.

Hasil penilaian e-magazine menggunakan flipcreator pada materi pertumbuhan dan perkembangan pada tumbuhan dikategorikan sebagai sumber belajar yang valid dan praktis, namun dalam penelitian terdapat beberapa kendala dalam pelaksanaan pengembangan sumber belajar, peneliti menggunakan aplikasi yang memiliki kapasitas yang besar sehingga peneliti harus menggunakan laptop yang memiliki kapasitas dan ROM yang besar. Maka dari itu, perlu adanya perbaikan seperti pencarian aplikasi yang memiliki spesifikasi lebih rendah untuk pengembangan sumber belajar.

Sumber belajar e-magzine menggunakan flipcreator dapat dikategorikan sebagai sumber belajar yang inovatif karena terdapat beberapa fitur-fitur tambahan seperti video pembelajaran, gambar berwarna, animasi, tulisan yang tidak monoton, dan informasi-informasi unik yang dapat menarik perhatian peserta didik untuk membaca dan mempelajari materi yang terdapat didalam sumber belajar e-magazine. Sejalan dengan pendapat Abdullah (2012) bahwa sumber belajar yang dapat dimanfaatkan untuk kebutuhan pembelajaran sangat beraneka ragam jenis dan bentuknya seperti bahan cetakan buku teks akan tetapi peserta didik dapat memanfaatkan sumber belajar yang lain seperti radio pendidikan, televisi, komputer, e-mail, video interaktif.

Kelebihan sumber belajar e-magazine menggunakan flipcreator yaitu dapat memuat file berupa video, gambar bergerak, atau animasi serta suara, sehingga akan sangat membantu dalam proses pembelajaran yang dapat membuat peserta didik tidak jenuh dalam melakukan aktifitas belajar. Berbeda dengan buku elektronik (e-book) lainnya yang hanya berbentuk file *.PDF atau *.doc yang memuat teks dan gambar diam saja. Selain itu, out put dari Kvisoft dapat disajikan secara online maupun offline serta dapat di sajikan melalui $P C$ ataupun handphone yang bersistem android.

Jika ditinjau dari kelebihan sumber belajar e-magazine menggunakan flipcreator, maka dapat dikatakan bahwa sumber belajar ini berpotensi dapat meningkatkan motivasi belajar peserta didik yang berdampak pada hasil belajar dengan melakukan uji keefektifan. Menurut Wenning (2015), peran dari motivasi dalam proses belajar begitu besar, sehingga guru harus membangun motivasi peserta didik untuk belajar pada materi yang akan disampaikan. Untuk mengindentifikasikan motivasi sebagai suatu penggerak, pengarah dan memperkuat tingkah laku. Oleh karena itu motivasi belajar tidak hanya merupakan energi yang menggerakan peserta didik untuk belajar, tetapi juga sebagai pengarah aktifitas peserta didik kepada tujuan akhir belajar agar hasil belajar maksimal.

Salah satu fitur tambahan pada sumber belajar e-magazine menggunakan flipcreator ini yaitu video pembelajaran. Pada materi pertumbuhan dan perkembangan pada tumbuhan, terdapat beberapa sub materi yang harus divisulisasikan sehingga sumber belajar e-magazine menggunakan flipcreator dinilai sangat sesuai untuk diterapkan dalam materi ini. Selain itu dengan adanya sumber belajar e-magazine menggunakan flipcreator peserta didik tidak akan 
Pengembangan Media Pembelajaran

E-Magazine sebagai Sumber Belajar Biologi Siswa Kelas XII

(hlm. 38-45)

jenuh membaca materi pelajaran ini meskipun dalam bentuk buku elektronik. Adanya video pembelajaran yang terdapat pada e-magazine berpotensi membantu pesera didik untuk memahami materi pertumbuhan dan perkembangan pada tumbuhan yang sangat tepat digunakan dengan menayangkan video pembelajaran.

Menurut Susilana (2007) menjelaskan bahwa video disebut juga gambar hidup (motion picture) yaitu, serangkaian gambar yang meluncur secara cepat, dan diproyeksikan sehingga berkesan seperti nyata. Video merupakan media yang menyajikan pesan secara audio visual dan gerak yang dapat memberikan pesan yang impresif bagi orang yang melihat. Dengan adanya video pembelajaran dan berbagai fitur tambahan pada sumber belajar e-magazine menggunakan flipcretaor sangat berpotensi untuk menarik perhatian peserta didik untuk memebaca dan dapat meningkatkan motivasi belajar peserta didik.

Motivasi belajar menjelaskan alasan mengapa peserta didik melakukan hal tertentu, membuat mereka terus melakukan itu, dan membantu meraka untuk menyelesaikan tugas. Konsep motivasi yang digunakan untuk menjelaskan keinginan peserta didik untuk berperilaku keararah intensitas belajar, dan prestasi yang nyata (Pintrich, 2003). Selain itu Kosoema (2009) menyatakan bahwa perubahan seseorang bergantung pada motivasinya untuk terlibat dalam proses perubahan itu sendiri. Motivasi belajar berfokus pada jawaban kognitif, seperti kecendrungan peserta didik untuk mencapai kegiatan akademik yang bermakna dan bermanfaat (Santrock, 2007). Peserta didik yang memiliki motivasi belajar, akan memberikan perhatian lebih terhadap proses belajar, sehingga mereka bisa mengerti isi materi dan penggunaan berbagai sumber pendukung yang dapat memudahkan dalam menyelesaikan tugas. Untuk mengetahui peningkatan motivasi dan hasil belajar dapat dilakukan dengan uji keefektifan seperti pemberian angket, tes evaluasi, dan wawancara, namun pada penelitian pengembangan e-magazine menggunakan flipcreator pada materi pertumbuhan dan perkembangan pada tumbuhan sebagai sumber belajar kelas XII SMA ini peneliti hanya menguji kevalidan dan kepraktisan sumber belajar.

\section{Kesimpulan}

Pengembangan media e-magazine menggunakan model pengembangan ADDIE yang terdiri atas 5 tahapan yakni Analysis (Analisis), Design (Perancangan), Development (Pengembangan) Implementation (implementasi) dan Evaluation (evaluasi). Analisis data uji kevalidan media mencapai $82 \%$ dengan kategori baik/valid, analisis data untuk uji kevalidan materi yaitu $81 \%$ dengan kategori baik/valid, uji kepraktisan media dari hasil respon guru mencapai 87\% kategori sangat positif dan uji kepraktisan media dari respon siswa yaitu 85\% kategori positif. Berdasarkan hasil penelitian maka dapat disimpulkan bahwa media pembelajaran e-magazine yang dikembangkan tergolong dalam kategori valid dan praktis.

\section{Referensi}

Abdullah. (2012). Pembelajaran Berbasis Pemanfaatan Sumber Belajar. Jakarta. Didaktika.

Falahudin, I. (2014). Pemanfaatan Media dalam Pembelajaran. Jurnal Lingkar Widyaiswara, 1 (4), 104-117.

Koesoema, D. A. (2009). Pendidik Karakter di Zaman Keblinger (Character education in crazy era). Jakarta. Grasindo.

Nugrahani, Rahina. (2007). Media Pembelajaran Berbasis Visual Berbentuk Permainan Ular Tangga Untuk Meningkatkan Kualitas Belajar Mengajar Di Sekolah Dasar. Semarang. 
Pintrich, P. R. (2003). A motivational science perspective on the role of student motivation in learning and teaching contexts. Journal of Educational Psychology, 95 (4), 667-686.

Rudi., Susilana. (2007). Media Pembelajaran. Bandung. CV. Wacana Prima.

Santrock, J. (2007). Child development. New York. McGrow.

Suherman, Y. (2009). Pengembangan Media Pembelajaran Bagi ABK. Diklat Profesi Guru PLB Wilayah X Jawa Barat.

Susilana, R. \& Riyana, C. (2007). Media Pembelajaran. Bandung. CV Wacana Prima.

Wening, U. H. (2015). Penggunaan Flip Book Terhadap Motivasi Belajar Siswa Kelas Xi Tkj Di Smk Pringsurat. Jawa Tengah. Skripsi. Fakultas Teknologi Informasi Universitas Kristen Satya Wacana.

Yamasari, Y. (2010). Pengembangan Media Pembelajaran Matematika Berbasis ICT yang berkualitas. Seminar Nasional Pascasarjana. X - ISBN No 979-545-0270-1.

Yulianto, E., Rohaeti, E. (2013). Pengembangan Majalah Kimia Untuk Meningkatkan Motivasi Belajar dan Kreatifitas Peserta Didik Kelas X SMAN 1 Melati. Jurnal Pendidikan, 1 (1), 4648.

\begin{tabular}{|l|l|}
\hline Ainul Fuad & $\begin{array}{l}\text { S.Pd. Jurusan Biologi, FMIPA, Universitas Negeri Makassar } \\
\text { Email: ainulfuad811@gmail.com }\end{array}$ \\
\hline Hilda Karim & $\begin{array}{l}\text { Ir, M.P, Dr. Dosen Jurusan Biologi, FMIPA, Universitas Negeri Makassar } \\
\text { Email: hildakarim@yahoo.com }\end{array}$ \\
\hline $\begin{array}{l}\text { Muhiddin } \\
\text { Palennari }\end{array}$ & $\begin{array}{l}\text { M.Pd, Dr. Dosen Jurusan Biologi, FMIPA, Universitas Negeri Makassar } \\
\text { Email: } \underline{\text { muhiddin.p@unm.ac.id }}\end{array}$ \\
\hline
\end{tabular}

